\title{
Preparation of School Counselors and Response to Intervention: A Profession at the Crossroads
}

Melissa S. Ockerman

DePaul University

Eva N. Parikakou

DePaul University

Amy Feiker Hollenbeck

DePaul University

Follow this and additional works at: https://via.library.depaul.edu/educfacpubs

Part of the Education Commons

\section{Recommended Citation}

Ockerman, M. S., Patrikakou, E., \& Feiker Hollenbeck, A. (2015). Preparation of School Counselors and Response to Intervention: A Profession at the Crossroads. The Journal of Counselor Preparation and Supervision, 7(3). http://dx.doi.org/10.7729/73.1106

This Article is brought to you for free and open access by the College of Education at Digital Commons@DePaul. It has been accepted for inclusion in Faculty Publications - College of Education by an authorized administrator of Digital Commons@DePaul. For more information, please contact digitalservices@depaul.edu. 


\section{The Journal of Counselor Preparation and Supervision}

Volume $7 \mid$ Number 3

2015

\section{Preparation of School Counselors and Response to Intervention: A Profession at the Crossroads}

Melissa S. Ockerman

DePaul University, Mockerma@depaul.edu

Eva Patrikakou

DePaul University, epatrika@depaul.edu

Amy Feiker Hollenbeck

DePaul University, AFEIKER@depaul.edu

Follow this and additional works at: https://repository.wcsu.edu/jcps

Part of the Disability and Equity in Education Commons, Educational Assessment, Evaluation, and Research Commons, Special Education and Teaching Commons, and the Student Counseling and Personnel Services Commons

\section{Recommended Citation}

Ockerman, M. S., Patrikakou, E., \& Feiker Hollenbeck, A. (2015). Preparation of School Counselors and Response to Intervention: A Profession at the Crossroads. The Journal of Counselor Preparation and Supervision, 7(3). http://dx.doi.org/10.7729/73.1106

This Article is brought to you for free and open access by WestCollections: digitalcommons@wcsu. It has been accepted for inclusion in The Journal of Counselor Preparation and Supervision by an authorized editor of WestCollections: digitalcommons@wcsu. For more information, please contact ir@wcsu.edu. 


\title{
Preparation of School Counselors and Response to Intervention: A Profession at the Crossroads
}

\begin{abstract}
As a result of the Response to Intervention (RTI) mandate in schools across many states, school counselors are uniquely positioned to a take a leadership role within its implementation. This research study examines how school counselors in one such state perceive their training and knowledge of RTI and thus their confidence in implementing it. Implications for training, supervision, professional development and future research are discussed.
\end{abstract}

\section{Author's Notes}

Correspondence addressing this article should be sent to Melissa S. Ockerman: Mockerma@depaul.edu

\section{Keywords}

School Counseling, Training, Response to Intervention 
Brought to national attention by the reauthorization of the Individuals with Disabilities Educational Improvement Act of 2004, and supported, delineated, and in some instances legally mandated by state departments of education across the country (Berkely, Bender, Peaster, \& Saunders, 2009; Zirkel \& Thomas, 2010; Zirkel, 2012), Response to Intervention (RTI) is an increasingly common framework in today's schools. RTI is best described as a multi-tiered service delivery model in which struggling students receive differentiated, research-based intervention per the demonstrated academic or behavioral needs. Rather than requiring a special education diagnosis prior to academic or behavioral supports, a child receives intervention first within an RTI framework. Therefore, RTI is conceptually founded upon a paradigm shift in education: from a student-centered deficit perspective in which a child needs a disability label to receive supports, to an ecological perspective in which quality and type of instruction are concrete factors that directly influence student learning (e.g., Buffum, Mattos, \& Weber, 2010; Kozleski \& Huber, 2010). The goal of RTI is to provide effective general instruction and databased intervention for all students who require such, with the aim of reducing the disproportionate representation of students of color (i.e., Black, Latino, and Native American) in special education (e.g., Donovan \& Cross, 2002; Gresham, 2001; L. Fuchs, Fuchs, \& Speece, 2002).

RTI frameworks share common characteristics, designed to support the goal of educational improvement and student success. From a national perspective, 17 states now require RTI in the process of identifying if a student has a specific learning disability (SLD), while 45 states have guidance documents in support of RTI (Hauerwas, Brown \& Scott, 2013). Across the majority of these states, RTI is conceptualized as a three-tier model, with each tier providing more specialized and individualized instruction (e.g., Berkeley et al., 2009; Zirkel, 2011). Tier 
one involves the general classroom, with the inclusion of specific elements that may not be integrated within a traditional general education environment: universal screening measures to identify students who are at risk for academic (and/or behavioral) failure and differentiated, research-based, small group instruction. If a student fails to thrive in this environment over a designated period of time, he or she is identified for tier two intervention, generally conceptualized as targeted small group instruction occurring two to three times per week. If the child remains non-responsive to intervention, he or she moves to tier three, which may involve 1:1 or 1:2 instruction outside of the classroom 4-5 times per week. Within tiers two and three, progress-monitoring tools are used to track student progress (or lack thereof) as well as to inform instruction, intervention, and movement between tiers (e.g., National Joint Committee on Learning Disabilities, 2005). Effective instruction within an RTI framework is supported by collaborative practices between school-based professionals (e.g., Bean \& Lillenstein, 2012) and strong leadership from a systemic perspective (Kozleski \& Huber, 2010; O’Conner \& Freeman, 2012). Ultimately, school-based professionals perceive RTI as a positive change when they have a proactive, knowledgeable principal who speaks confidently about the reform, as well as other building-level leaders in support of the initiative (Hollenbeck \& Patrikakou, 2014).

Due to the fundamental shifts in practice within RTI, school-based professionals report taking on new or additional responsibilities when working within the framework. For example, observations and interviews with teachers of reading (including specialists, coaches, and classroom teachers) indicated professionals were more actively engaged in collaborative practices following the implementation of RTI (Bean \& Lillenstein, 2012). Additionally, researchers found school psychologists spent up to $25 \%$ of their day providing intervention within an RTI framework, in comparison to $5 \%$ of the time for those who were not involved with 
RTI (Sullivan \& Long, 2010). At this time, however, there has been limited exploration of school counselors' beliefs and attitudes toward RTI, as well as the effect on their professional practice.

Concomitant with the reform-centered shifts within education, the school counseling profession has also undergone significant change (American School Counseling Association [ASCA] 2003, 2005, 2012); Education Trust, 1996; NOSCA, 2011), positioning school counselors into roles of leadership and social justice advocacy (Martin, 2002; Ockerman, Mason \& Novakovic, 2012; Perusse \& Goodnough, 2001; Sears, 1999). In the ASCA National Model (2003, 2005, \& 2012), school counselors create, implement, and evaluate comprehensive developmental school counseling programs that reach all students, particularly marginalized and historically underserved students. Within this model, counseling interventions are delivered and evaluated via a tiered system, similar to that of RTI frameworks (see Ockerman, Mason \& Hollenbeck, 2012, for full discussion). Specifically, these tiers involve core curriculum and class-wide instruction for all students (aligning with tier one of RTI), small group, skill-based, and peer support services in tier two (aligning with tier two of RTI) and individual counseling and/or agency referral (aligning with tier three of RTI) (ASCA, 2012; Ockerman et al., 2012). Counseling interventions must be evidence-based as well as predicated on data garnered from school records and needs assessments. Moreover, assessment tools should be used to evaluate the efficacy of counseling interventions.

In 2008, ASCA developed a position statement related to school counselors' roles in an RTI framework. Despite this development, review of literature yields little evidence-based practice regarding how to prepare school counselors to work within this model. The RTI Action Network (2009) provided direction in its Voices from the field piece, denoting how a few school counselors in Colorado, Oklahoma, and Wyoming were able to contribute to and participate 
within their school-based RTI teams. Others, such as Miller (2008), Luck and Webb (2009) and Ryan, Kaffenberger and Carroll (2011), documented success in relation to implementing tiered school counseling services and evidence-based academic achievement programs in elementary and middle school counseling programs in Florida, Georgia and Virginia, respectively. For example, researchers found that student outcomes and achievement improved when school counselors facilitated classroom lessons (tier 1) and small groups (tier 2) using the evidencebased Student Success Skills curriculum (Brigman \& Campbell, 2003; Luck \& Webb, 2008; Webb, Brigman \& Campbell, 2005). Moreover, calls for more focused, collaborative efforts between school-based mental health providers have been evidenced in response to RTI (Zambrano, Castro-Villarreal, \& Sullivan, 2012).

Despite these efforts, there remains a dearth of research related to the preparation of school counselors in the context of RTI. The authors of this manuscript believe there is a unique opportunity, and responsibility, for school counselor educators and supervisors to prepare emerging and practicing school counselors to effectively serve all students. This requires a contextual understanding of RTI as an educational reform and the belief that leveraging RTI can serve to advance school counseling services and programs (Ockerman et al., 2012). School counselors in Illinois were at the forefront of a mandated statewide RTI implementation, and thus their experiences can inform the development and training needs in states yet to fully adopt RTI. Following the IDEA reauthorization of 2004, the state of Illinois quickly piloted and subsequently required RTI as a K-12 instructional and intervention model for academic and behavioral support (Adkins, 2007), with an implementation deadline of September 2010 (Illinois State Board of Education, 2008). Data for this paper were gathered subsequent to the 2010 implementation deadline to provide insight into school counselors' RTI beliefs and practices. 
Students in the state of Illinois can be seen to represent the national profile of learners demographically, creating a case study with implications for preparation and professional practice. The student population in Illinois consists of $51 \%$ of students identified as White (in comparison to $52 \%$ nationally), $23 \%$ Hispanic (24\% nationally), and $18 \%$ Black (16\% nationally). Of these students, $8 \%$ are identified with Limited English Proficiency (in comparison to $13 \%$ nationally), and $44 \%$ percent are indicated as low income as measured by Free and Reduced Price Lunch status (48\% of students nationally) (US Department of Education, 2011a \& b). Understanding the experiences of school counselors in one state adopting RTI can inform future training initiatives in the Midwest and beyond. For this purpose, the present study will investigate the following:

\section{Research Questions}

1) What are Illinois school counselors' beliefs regarding RTI?

2) How confident are school counselors regarding their training on the various implementation aspects of RTI?

3) To what degree have the responsibilities of school counselors changed due to the RTI implementation?

4) Which aspects of RTI consume most of the school counselors' time?

5) Is attitude toward RTI predicted by factors including perceived confidence with various aspects of the framework?

\section{Method}

Members of the Illinois School Counselors Association (ISCA) were selected for involvement in this study. A link to an electronic survey, created in SurveyMonkey, as well as an informational sheet for research participation, were disseminated to the membership of the ISCA 
listserve in a mass email after Institutional Review Board and ISCA permissions were obtained. Research processes and analysis adhered to the American Counseling Association (ACA) Code of Ethics (2014) and the American School Counseling Association (ASCA) Ethical Standards (2010). Seventy-five of the 411 ISCA members completed the survey in its entirety. This yielded a response rate of approximately 18\%, which is higher to that of other online surveys (for example, see Cochrane \& Laux, 2008; Sullivan, Long, \& Kucera 2011).

Ninety-seven percent of survey respondents reported working in public school settings. Nineteen percent indicated working in an elementary setting, $8 \%$ in an elementary/middle school, $16 \%$ in middle school, and $57 \%$ in high school. Forty-four percent reported having a Masters +30 continuing education hours, and $8 \%$ held a doctorate, with $67 \%$ noting five or more years since their last degree conferral. Seventy-three percent of respondents reported five or more years of practice in the field, with $60 \%$ at their current position for five years or more. The average caseload reported was 335 students, with the median and mode of 300 students.

\section{Measures}

The survey used in this study is an adaptation of a tool developed for a statewide study of school professionals in response to RTI (see Hollenbeck \& Patrikakou, 2014). The original survey was developed after an extensive review of literature across the following areas: importance of RTI training (e.g., Danielson, Doolittle, \& Bradley, 2007; Kratochwill, Volpiansky, Clements, \& Ball, 2007), impact of experience in the field and educational level (e.g., Hargreaves, 2005; Sullivan \& Long, 2010), research-based components of RTI implementation (e.g., Buffum et al., 2010; National Joint Committee on Learning Disabilities, 2005), and leadership competence in educational reform (e.g., Fullan, 2002; Leithwood, Day, Sammons, Harris, \& Hopkins, 2006; Marzano, Waters, \& McNulty, 2005). In revising the survey 
for school counselors, the authors added items to align with the ASCA National Model (2003, 2005 \& 2012), including counselor interventions at each tier, data collection and management, and collaborative practices.

The survey for school counselors consisted of five sections. The first section included ten questions addressing demographics (e.g., highest degree obtained, number of years at current school). The second section involved five multiple-choice questions regarding RTI training (e.g., How many professional development trainings have you received to date in relation to RTI? Who provided those trainings?). The third section contained 14 Likert-type items asking participants about their perceived level of confidence towards specific aspects of RTI (e.g., How confident do you feel about counseling interventions for tier one?). Open-ended questions also allowed participants to add, or expand on, their perspectives (e.g., Additional areas of need, not previously identified). The fourth section included eight Likert-type questions measuring participants' beliefs about the specific RTI implementation in their school and perceived outcomes (e.g., I believe RTI is the best option to support struggling learners and students with socio-emotional concerns). In addition, a 20-item section addressed the frequency of completion of RTI-related tasks (e.g., I measure progress of my school-wide interventions through pre/post tests). Participants selected their responses from a Likert scale that offered six frequency options.

\section{Procedure}

The school counselor survey was piloted at the Annual Conference of The Illinois School Counselor Association. The first author asked conference attendees to complete an anonymous paper copy of the survey and leave it in a collection box, with directions to note any areas of confusion regarding questions. Ten pilot participants completed the survey, and final adjustments were made to the instrument regarding clarify of wording items. At this time the survey was 
converted to an electronic data collection platform, SurveyMonkey, for dissemination through the ISCA listserve.

\section{Scales}

For the purpose of this study's analyses, eight scales were constructed. As a measure of internal consistency, Cronbach's Alpha was computed for each of the eight scales (scale items and reliability coefficients are reported in Table 1). Alpha coefficients ranged from .68 to .92, with the majority over .80.

Table 1

Scale Items and Cronbach's Alpha Coefficients

\begin{tabular}{|c|c|c|}
\hline $\begin{array}{l}\text { Variables } \\
\text { (number of items included) }\end{array}$ & Sample Items & 's $\alpha$ \\
\hline $\begin{array}{l}\text { RTI Background Information } \\
\text { (2) }\end{array}$ & Underlying rationale & .80 \\
\hline $\begin{array}{l}\text { Responsibilities \& benefits } \\
\text { (2) }\end{array}$ & $\begin{array}{l}\text { Anticipated benefits } \\
\text { Roles and responsibilities within the tiered } \\
\text { model }\end{array}$ & .70 \\
\hline $\begin{array}{l}\text { Tier service delivery model } \\
\text { (2) }\end{array}$ & $\begin{array}{l}\text { Tier service delivery model } \\
\text { (specific to one's school) }\end{array}$ & .80 \\
\hline $\begin{array}{l}\text { Counseling interventions } \\
\text { (3) }\end{array}$ & for tiers $1,2, \& 3$ & .90 \\
\hline $\begin{array}{l}\text { Data collection \& management } \\
\text { (3) }\end{array}$ & $\begin{array}{l}\text { School-wide data management systems for } \\
\text { documentation and decision making about } \\
\text { students who need supportive services within } \\
\text { RTI }\end{array}$ & .92 \\
\hline $\begin{array}{l}\text { Collaborative practices } \\
\text { (3) }\end{array}$ & $\begin{array}{l}\text { Collaborative practices in an RTI framework } \\
\text { Increasing parental involvement in RTI }\end{array}$ & .85 \\
\hline $\begin{array}{l}\text { School building leadership \& } \\
\text { RTI competence } \\
\text { (4) }\end{array}$ & $\begin{array}{l}\text { Principal appears highly knowledgeable } \\
\text { about RTI }\end{array}$ & .85 \\
\hline $\begin{array}{l}\text { RTI viewed as beneficial } \\
\text { (4) }\end{array}$ & $\begin{array}{l}\text { RTI can improve the academic and } \\
\text { behavior outcomes of all students }\end{array}$ & .68 \\
\hline
\end{tabular}




\section{Data Analysis}

Descriptive statistics were generated to address the first four research questions, and a regression model was constructed to address the final question. The following independent variables were regressed on the dependent variable of the perceived benefit of RTI: highest degree, years since highest degree conferral, total years in practice, total years in current school, number of trainings received, and implementation date before or after the mandatory 2010 statewide implementation. The following were used as variables representing the perceived level of confidence of respondents across eight areas related to RTI: background knowledge, roles and responsibilities, tiered service delivery model, research-based practices, data collection and management, collaborative practices, and leadership competence.

\section{Results}

Results are presented in relation to each of the five research questions in turn.

\section{Research Question 1: What are Illinois school counselors' beliefs regarding RTI?}

The majority of the respondents, $83 \%$ percent, either agreed $(66 \%)$ or strongly agreed (17\%) with the statement that RTI can improve the academic and the behavior outcomes of all students. Two-thirds (66\%) agreed that RTI is a vehicle of promoting culturally responsive practices, while $72 \%$ agreed that RTI is the best option to support struggling learners and students with social and emotional concerns. Eighty percent of participants indicated that their principal described RTI in a positive, enthusiastic manner, 61\% reported that their principal seemed knowledgeable about RTI, and 56\% reported that other building leaders seemed knowledgeable about RTI. When reporting on school climate, about half (56\%) of participants indicated that RTI-related concerns and challenges were addressed in a positive manner, and $46 \%$ reported that the majority of their colleagues were in favor of an RTI framework. 


\section{Research Question 2: How confident are school counselors regarding their training on the various implementation aspects of RTI?}

Thirty-seven percent of participants reported that they first heard about RTI at a buildinglevel meeting, whereas $32 \%$ reported first learning about RTI at a district-level meeting. Forty percent reported their school implemented the RTI framework in, or prior to, 2009; $43 \%$ reported RTI implementation during or following 2010; while 17\% did not know when their school implemented RTI. Eleven percent of participants did not receive any professional training in relation to RTI. Thirty-seven percent reported one to two trainings, 39\% three to six trainings, and $13 \%$ more than seven trainings. Over a third of participants reported as that they were at least satisfied with their training (32\% satisfied; $6 \%$ highly satisfied).

The five training areas in which more than $40 \%$ of participants reported little confidence are as follows, in descending order: how to increase parent involvement in relation to RTI (54\%), collaborative practices in an RTI framework (41\%), collecting and analyzing data to determine effectiveness of RTI interventions (40\%), using progress monitoring data to inform counseling interventions within an RTI framework (40\%), and school-wide data management systems for documentation and decision making about students (39\%). The five training areas in which participants indicated their highest confidence are as follows: underlying rational of RTI (55\%), anticipated benefits of RTI (54\%), general tiered service-delivery model (54\%), counseling interventions for tier 1 (41\%), and counseling interventions for tier $3(37 \%)$ (see table 2 for details). 
Table 2

Confidence on Different Aspects of RTI

\begin{tabular}{|c|c|c|c|}
\hline & $\begin{array}{l}\% \quad \text { Little } \\
\text { Confidence }\end{array}$ & $\begin{array}{l}\% \quad \text { Some } \\
\text { Confidence }\end{array}$ & $\begin{array}{l}\% \quad \text { High } \\
\text { Confidence }\end{array}$ \\
\hline Historical overview of RTI & 24 & 50 & 26 \\
\hline Underlying rationale of RTI & 9 & 36 & 55 \\
\hline Anticipated benefits of RTI & 4 & 42 & 54 \\
\hline Tiered service-delivery model - general & 13 & 33 & 54 \\
\hline Tiered $\begin{array}{l}\text { service delivery model }- \text { school } \\
\text { specific }\end{array}$ & 23 & 48 & 29 \\
\hline $\begin{array}{l}\text { Role and responsibilities within the tiered } \\
\text { model }\end{array}$ & 23 & 48 & 29 \\
\hline Counseling interventions for tier 1 & 20 & 39 & 41 \\
\hline Counseling interventions for tier 2 & 20 & 46 & 34 \\
\hline Counseling interventions for tier 3 & 24 & 39 & 37 \\
\hline $\begin{array}{c}\text { Collecting and analyzing data to determine } \\
\text { effectiveness of RTI interventions }\end{array}$ & 40 & 34 & 26 \\
\hline $\begin{array}{l}\text { Using progress monitoring data to infor } \\
\text { counseling interventions in RTI }\end{array}$ & 40 & 41 & 19 \\
\hline $\begin{array}{l}\text { School-wide data management systems for } \\
\text { documentation \& decision making }\end{array}$ & 39 & 37 & 24 \\
\hline Parental involvement in an RTI framework & 54 & 36 & 10 \\
\hline Collaborative practices in an RTI framework & 41 & 39 & 20 \\
\hline
\end{tabular}

\section{Research Question 3: To what degree have the responsibilities of school counselors changed due to RTI implementation?}

Nineteen percent of participants reported that their responsibilities have not changed due to RTI implementation. The majority (67\%) reported that their responsibilities have changed $40 \%$ or less. The three most frequently identified changes were as follows: "I now collaborate 
with colleagues as part of an RTI team" (70\%); "I now provide tier 2 and/or tier 3 interventions to struggling students" (54\%); and, "I am now involved in data collection and/or data management in support of RTI decisions" (52\%).

\section{Research Question 4: Which aspects of RTI consume most of the school counselors' time?}

Respondents identified the following responsibilities as being performed either daily or weekly: involvement with case management for students with academic concerns (65\%), implementation of tier 3 counseling interventions (64\%), involvement with case management for students with social-emotional concerns (58\%), support of teachers with academic interventions (51\%), and provision of academic interventions directly to students (46\%). The four activities in which a high percentage of participants reported no involvement are as follows: "measure progress of interventions with individual students through pre/post tests" (70\%), "measure progress of my school-wide interventions through pre/post test (55\%), "measure progress of my small group/peer support interventions through pre/post tests (54\%), and "collect data about the needs of student through needs assessments to better inform culturally relevant practices in my school" (49\%; see table 3 for detailed response percentages). 
Table 3

\begin{tabular}{|c|c|c|c|c|c|c|}
\hline$\underline{\text { Dai }}$ & & Weekly & Monthly & Quarterly & Yearly & Not at all \\
\hline & Perc & & & & & \\
\hline Frequency of Completing the Following & task & Relatio & RTI Impl & ntation & & \\
\hline $\begin{array}{llll}\text { Implement } & \text { Tier } & 1 & \text { counseling } \\
\text { interventions } & & & \end{array}$ & 16 & 27 & 22 & 14 & 8 & 13 \\
\hline $\begin{array}{l}\text { Measure progress of my school-wide } \\
\text { interventions through pre/post tests }\end{array}$ & 0 & 2 & 19 & 18 & 6 & 55 \\
\hline Implement Tier 2 counseling interventions & 8 & 32 & 14 & 12 & 3 & 31 \\
\hline $\begin{array}{l}\text { Measure progress of my small group/peer } \\
\text { support interventions through pre/post }\end{array}$ & 0 & 5 & 20 & 19 & 2 & 54 \\
\hline Implement tier 3 counseling interventions & 28 & 35 & 11 & 5 & 2 & 19 \\
\hline $\begin{array}{l}\text { Measure progress of my interventions with } \\
\text { individual students through pre/post tests }\end{array}$ & 0 & 3 & 14 & 11 & 2 & 70 \\
\hline $\begin{array}{l}\text { Support teachers with academic interventions } \\
\text { directly to students }\end{array}$ & 14 & 37 & 22 & 8 & 3 & 16 \\
\hline $\begin{array}{l}\text { Provide academic interventions directly to } \\
\text { students }\end{array}$ & 16 & 30 & 6 & 8 & 2 & 38 \\
\hline $\begin{array}{l}\text { Being involved with case management for } \\
\text { students with social-emotional concerns }\end{array}$ & 29 & 28 & 21 & 3 & 2 & 17 \\
\hline $\begin{array}{l}\text { Being involved with case management for } \\
\text { students with academic concerns }\end{array}$ & 27 & 38 & 16 & 1 & 0 & 18 \\
\hline $\begin{array}{l}\text { Collect data about the needs of students through } \\
\text { needs assessments to better inform RTI } \\
\text { interventions }\end{array}$ & 3 & 14 & 19 & 18 & 11 & 35 \\
\hline $\begin{array}{l}\text { Collect data about the needs of students through } \\
\text { needs assessments to better inform culturally } \\
\text { relevant practices in my school }\end{array}$ & 3 & 6 & 15 & 11 & 16 & 49 \\
\hline $\begin{array}{l}\text { Examine school-wide data to determine RTI } \\
\text { counseling interventions }\end{array}$ & 2 & 17 & 13 & 25 & 16 & 27 \\
\hline $\begin{array}{l}\text { Discuss standardized test data with relevant } \\
\text { parties }\end{array}$ & 2 & 9 & 27 & 33 & 13 & 16 \\
\hline $\begin{array}{l}\text { Coordinate efforts and ensure proper } \\
\text { communication between RTI team members, } \\
\text { students, and family members }\end{array}$ & 3 & 22 & 24 & 14 & 8 & 29 \\
\hline $\begin{array}{l}\text { Train or present information to my colleagues } \\
\text { about RTI interventions }\end{array}$ & 0 & 5 & 6 & 8 & 22 & 59 \\
\hline $\begin{array}{l}\text { Train or present information to my colleagues } \\
\text { about how to gather and analyze RTI data }\end{array}$ & 0 & 0 & 8 & 11 & 16 & 65 \\
\hline
\end{tabular}




\section{Research Question 5: Is attitude toward RTI predicted by factors including perceived confidence with various aspects of the framework?}

The full regression model accounted for $51 \%$ of the variance in perception of RTI as a beneficial change. Two variables were statistically significant: perceived leadership competence $(\underline{\beta}=.35 ; \underline{p}<.01)$, and understanding the specific roles, responsibilities and benefits of RTI $(\underline{\beta}$ $=.52 ; \mathrm{p}<.05$ ). If school counselors (a) perceived building-level leaders as knowledgeable and positively predisposed to RTI, and (b) were confident in understanding their roles and responsibilities within an RTI model, as well as its potential benefits, they were more likely to view RTI as a vehicle to drive improvements in academic and behavior outcomes for all students.

\section{Discussion}

The findings of this study have implications for both pre-service preparation and professional development of practicing school counselors. Driven by national efforts exploring school counselor preparation, the College Board found that $28 \%$ of the 5300 school counselors surveyed viewed their graduate level training as insufficient preparation for their role as school counselors, and 56\% reported feeling "somewhat" prepared for the challenges they face (NOSCA, 2011). Likewise, in this current study, although the overwhelming majority of survey respondents believed RTI could improve academic and behavioral outcomes, over $40 \%$ had little confidence in their abilities to execute the following key roles: (1) increase parental involvement, (2) engage in collaborative practices, and (3) analyze and use data to make decisions about student needs. Yet, data management and collaborative practice are among the duties reported as most significantly changed since RTI was implemented in their schools. Given this disconnect between perceived confidence and assignment of current responsibilities, the authors argue for 
concerted preparation efforts in these areas for both pre-service and practicing school counselors. In addition, two variables were found to influence school counselors beliefs' towards RTI: Those respondents with positive, proactive leaders and a clear understanding of their own roles and responsibilities in relation to RTI were more likely to view the initiative as benefiting student outcomes. Therefore, we believe RTI provides an impetus for school counselors to proactively define their responsibilities and leverage their knowledge base as part of the school leadership team.

\section{Parental Involvement}

Actively engaging parents/guardians in their children's educational process has long been understood to yield positive results (Patrikakou, 2004, 2008). Despite this, there remains little emphasis on parental involvement in the RTI process, and parents may be confused about new terminology and procedures for access to special education (Bryd, 2011). Therefore, highlighting opportunities for school counselor involvement in this area should be a goal at both the preservice and in-service levels. The need for outreach to parents becomes even more pronounced when one considers the academic, social, and emotional benefits that stem from fostering schoolfamily partnerships (Patrikakou, Weissberg, Redding, \& Walberg, 2005).

Bryd (2011) recommends a systematic approach to increasing parental involvement in the RTI process. For the school counselor, this process should begin with a needs assessment of current levels of parental involvement and the development of three to five year goals for increasing involvement, as part of a comprehensive school counseling plan. For example, the school counselor, working as a member of the RTI leadership team, could organize a quarterly RTI open house, in which parents would receive information about key aspects of RTI, including the educational "jargon" that is often seen by parents a roadblock to involvement (Pena, 2000). 
These open houses could also include hands-on experiences with intervention materials used by students. Linking interventions to strategies and resources that can be utilized at home would optimize parental involvement, so families could best support the learning needs of their children. Furthermore, the school counselor could organize and lead RTI support groups to help parents process and understand their child's learning challenges. The school counselor should also be an advocate for parental rights within the RTI process, as sometimes RTI can be perceived or presented as a roadblock to special education (US Department of Education, 2011). The school counselor's parental involvement plan, with its related short and long-term goals, should be assessed on an ongoing basis through the use of tools such as parent surveys and interviews. Ongoing data collection and analysis can support the school counselor's development of outreach programming that is highly specific and useful to the parent population of the school (Bryd, 2011).

\section{Collaborative Practices}

In addition to partnering with families, school counselors must form collaborative partnerships with all stakeholders-forging synergies amongst and between key individuals within a student's ecosystem (ASCA, 2003, 2005 \& 2012; McMahon, Mason, \& Paisley, 2009). Specifically, when participating in an RTI team, the school counselor should help parents/guardians, administrators, teachers, and support personnel identify and track the efficacy of evidence-based best practices for students. Using their facilitative skills, school counselors can lead this effort not only during meetings but also by following-up with each party to ensure continuity of care. School counselors can foster a collaborative spirit by creating common ground and sharing accountability for results (ASCA, 2012), drawing upon strengths of stakeholders' contributions, and managing expectations (Chen-Hayes, Ockerman, \& Mason, 
2014). They may also create necessary paper-based and electronic processes to help increase efficiency among and between multiple parties (Chen-Hayes et al., 2014; Perry, 2007). Providing pre-service counselors with these opportunities during practicum and internship is paramount to their success in these endeavors after graduation. Thus, counseling students should be evaluated on group school-based assignments, with special attention given to teaming and collaborative practices (Education Trust, 2003). Professional development regarding how best to form teams to capitalize upon different communication styles and skill sets, as well as to create feedback loops, should be part of the on-going training of school counselors, especially when national reform efforts, such as RTI, are mandated.

\section{Using data and data-management systems to document services and make decisions}

The ability to collect and analyze data is integral to a school counselor's role. As noted by Hatch (2013), "using data to drive decisions ensures every student receives the benefit of a school counseling program that is preventative in design, developmental in nature, and comprehensive in scope" (p. 52). As such, school counselors must determine the needs of stakeholders through using readily available data (report cards, discipline records, attendance reports, graduation rates, etc.) and by creating and implementing needs assessments. Ockerman and colleagues (2012) asserted that this data-based skill set positions school counselors as integral members of RTI teams. Specifically, school counselors can administer needs assessments prior to interventions to establish baseline (academic, personal/social and college/career) and to determine the most urgent needs. Moreover, they can evaluate their efforts through both formal and informal assessments (pre/post tests, surveys, interviews, etc.) to create efficacy in helping students meet desired goals. 
The transformed role of the school counselor emphasizes dismantling the pervasive achievement gap for poor and marginalized populations. This substantial paradigm shift (Martin, 2002; Ockerman et al., 2012) is congruent with the foundational roots of RTI, aiming to reduce the disproportionate representation of students of color in special education settings (Newell \& Kratochwill, 2007). By proactively reviewing data about who is receiving special services and who is not, school counselors can champion equitable distribution of services for all students and thus contribute to important data-driven decisions within the RTI structure (Chen-Hayes et al., 2014). School counseling preparation programs must integrate such data-driven and assessmentbased components into both curricular and experiential activities. Furthermore, seasoned school counselors, as indicated by the results of our survey, could benefit from advanced training to become competent in these necessary skills.

\section{Leadership and Role Definition}

The results of this study indicate that school counselors who perceive their school leaders as highly knowledgeable and enthusiastic about the implementation of RTI and are confident with their roles and responsibilities within the framework are more likely to view RTI as a viable means of improving student outcomes. Prior research on the influence of leadership upon reform supports the idea that if the principal/dean and other building leaders are supportive and proactive in the implementation of change, so too are school faculty and support staff (e.g., Green \& Cypress, 2009; Leithwood et al., 2006; Hollenbeck \& Patrikakou, 2014; Penlington, Kington, \& Day, 2008). Conversely, if leadership actively oppose or are apathetic towards reform implementation, staff and faculty will follow suit. This finding underscores an opportunity for school counselors to positively engage with RTI to the benefit of the entire school faculty and students (Ockerman et al., 2012; Ryan et al., 2011), as it is not just the 
principal, but also other building leaders, that set the tone in relation to change. Specifically, school counselors can help others understand how collaborative data-driven decision making can aid children in learning, reduce unnecessary referrals to special education, limit concerns about equity and access, and simultaneously advance comprehensive school counseling programs. The authors urge school counselors to recognize and embrace this opportunity to help lead sustained and systemic change, responding with tenacity and intention to this national reform effort.

In addition to proactive leadership, school counselors who had a clear understanding of their own roles and responsibilities were most likely to view RTI as a vehicle that could drive academic and behavioral outcomes for all students. These same results were also documented in a state survey of various educational professionals (i.e., school psychologists, special educators, and general educators), in which school psychologists were most positive about RTI when they had proactive leadership and a clear understanding of their own roles and responsibilities (Hollenbeck \& Patrikakou, 2014). The authors posit that those professionals that have had historically less regimented duties than those of educators, benefit greatly from a clear idea of how an educational reform influences and aligns with their specific professional practices. Therefore, we believe school counselors should leverage the advent of RTI to proactively define their roles by advocating for tasks compatible with their unique skill set (Ockerman et al., 2012). In addition, it is important for the school counselor's Annual Agreement (ASCA, 2012) to delineate these duties. Specifically, the Agreement can be used to list specific responsibilities, school counseling curriculum, and program components that will promote RTI services (at all three tiers) while also identifying areas of need for professional development (ASCA, 2012). It is time for school counselors to proactively engage in defining their professional roles and responsibilities, thus maximizing their effectiveness with all students. 


\section{Limitations}

Although this study provides important information regarding the effects of RTI training on school counselors' confidence and perceptions in the context of substantial statewide implementation, some limitations must be recognized. First, inherent in survey research is the potential influence of the self-selectivity of participants on study outcomes. Based on this argument, the sample used in this study may not be representative of the broader membership of practicing school counselors, therefore limiting the generalizability of findings. Furthermore, the lack of data regarding participants' gender, ethnicity, and age makes it difficult to ascertain if the sample represents the broader population of school counselors across the state. An additional limitation of any anonymous, self-reported information is the lack of verification of reported data, as well as the confirmation that only eligible individuals filled out the survey.

\section{Future Directions}

While this Illinois-based study is instructive, a national study is needed to examine school counselors' preparedness, especially in states implementing RTI. A survey of this magnitude would foster a more comprehensive view of practicing school counselors and thus assist school districts in addressing professional development needs. Moreover, it is imperative that counselor educators be vigilant about including RTI in their curriculum in introductory and school counselor special education courses, as well as within practicum and internship experiences, to ensure the next generation of school counselors are best prepared to meet student needs. The implementation of RTI creates a prodigious opportunity for school counselors to lead trailblazing efforts within their schools and communities. They are poised at a unique crossroads; positioned to interface with administrators, staff, students and families to promote positive academic, personal/social and career/college outcomes for all students. 


\section{References}

Adkins, G. (2007, November). State pilots sweeping changes in special ed. The Education Digest. Retrieved from www.eddigest.com.

American Counseling Association (2014). ACA Code of Ethics. Alexandria, VA: Author.

American School Counselor Association. (2010). Ethical standards for school counselors. Alexandria, VA: Author.

American School Counselor Association (2003). The ASCA national model: A framework for school counseling programs. Alexandria, VA: Author.

American School Counselor Association (2005). The ASCA national model: A framework for school counseling programs (2nd Ed). Alexandria, VA: Author.

American School Counselor Association (2012). The ASCA national model: A framework for school counseling programs (3rd ed). Alexandria, VA: Author.

Bean, R., \& Lillenstein, J. (2012). Response to intervention and the changing roles of schoolwide personnel. The Reading Teacher, 65(7), 491-501. doi: 10.1002/TRTR.01073

Berkeley, S., Bender, W. N., Peaster, L. G., \& Saunders, L. (2009). Implementation of response to intervention: A snapshot of progress. Journal of Learning Disabilities, 42, 85-95. doi: $\underline{10.1177 / 0022219408326214}$

Buffum, A., Mattos, M., \& Weber, C. (2010). The why behind RTI. Educational Leadership, 68, 10-16.

Brigman, G. \& Campbell, C. (2003). Helping students improve academic achievement and school success behavior. Professional School Counseling, 7(2), 91-98.

Bryd, S. E. (2011). Educating and involving parents in the Response to Intervention process: The school's important role. Teaching Exceptional Children, 43(3), 32-39. 
Chen-Hayes, S.F., Ockerman, M.S., \& Mason, E.C.M. (2014) 101 solutions for school counselors and leaders in challenging times. Thousand Oaks, CA: Corwin Press.

Cochrane, W. S., \& Laux, J.M. (2008). A survey investigating school psychologists' measurement of treatment integrity in school-based interventions and their beliefs about its importance. Psychology in the Schools, 46(6), 499-507. doi: 10.1002/pits.20319

Danielson, L., Doolittle, J., \& Bradley, R. (2007). Professional development, capacity building, and research needs: Critical issues for response to intervention implementation. School Psychology Review, 36, 632-637.

Donovan, M. S., \& Cross, C. T. (Eds.). (2002). Minority students in special and gifted education. Washington, DC: National Academy Press.

Education Trust (2003). School counselors working for social justice. Retrieved from http://www2.edtrust.org/EdTrust/Transforming+School+Counseling/Social+Justice.htm

Education Trust (2011). The new vision of school counseling. Retrieved from http://www.edtrust.org/dc/tsc/vision.

Fuchs, L. S., Fuchs, D., \& Speece, D. L. (2002). Treatment validity as a unifying construct for identifying learning disabilities. Learning Disability Quarterly, 25, 33-44. doi:10.2307/1511189

Fullan, M. (2002). The change leader. Educational Leadership, 59(8), 16-21.

Green, R. \& Cypress, S. L. (2009). Instructional leadership: A model for change in alternative middle schools. Middle Grades Research Journal, 4(3), 19-40.

Gresham, F. (2001). Responsiveness to intervention: An alternative approach to the identification of learning disabilities. Washington, D.C.: Department of Education, Office of Special Education Programs. 
Hargreaves, A. (2005). Educational change takes ages: Life, career and generational factors in teachers' emotional responses to educational change. Teaching and Teacher Education, 21, 967-983. doi: 10.1016/j.tate.2005.06.007

Hatch, T. A. (2013). The use of data in school counseling: Hatching results for students, programs, and the profession. Thousand Oaks, CA: Corwin Press

Hauerwas, L. B., Brown, R., \& Scott, A. N. (2013). Specific learning disability and Response to Intervention: State-level guidance. Exceptional Children, 80(1), 101-120.

Hollenbeck, A. F. \& Patrikakou, E. N. (2014). Response to Intervention in Illinois:

An exploration of school professionals' attitudes and beliefs. Manuscript under review.

Illinois State Board of Education (2008). The Illinois State Response to Intervention (RtI) Plan. Retrieved from http://www.isbe.net/RtI_plan/default.htm.

Individuals with Disabilities Education Improvement Act (IDEA) of 2004, PL 108-446, 20 USC $\S 1400$ et seq.

Kozleski, E. B., \& Huber, J. J. (2010). Systemic change for RTI: Key shifts for practice. Theory Into Practice, 49, 258-264. doi: 10.1080/00405841.2010.510696

Kratochwill, T. R., Volpiansky, P., Clements, M., \& Ball, C. (2007). Professional development in implementing and sustaining multitier prevention models: Implications for response to intervention. School Psychology Review, 36, 618-631.

Leithwood, K., Day, C., Sammons, P., Harris, A., \& Hopkins, D. (2006). Seven strong claims about successful school leadership. Nottingham, UK: National College for School Leadership. Retrieved from_http://www.leadershipinnovationsteam.com/files/sevenstrong-claims.pdf. 
Luck, L. \& Webb, L. (2009). School counselor action research: A case example. Professional School Counseling, 12(6), 408-412.

Martin, P. J. (2002). Transforming school counseling: A national perspective. Theory

into Practice, 41(3), 148-153. doi:10.1207/s15430421tip4103_2

Marzano, R., Waters, T. \& McNulty, B. (2005). School leadership that works. Alexandria, VA: Association for Supervision and Curriculum Development.

McMahon, H. G., Mason, E. C. M., \& Paisley, P. O. (2009). School counselor educators as educational leaders promoting systemic change. Professional School Counseling, 13 (2), 107-115.

Miller, N.J. (2008). Pyramid of interventions: Results of a school counselor's action research study at one suburban middle school. GSCA Journal, 1(1). 16-26.

National Joint Committee on Learning Disabilities. (2005). Responsiveness to intervention and learning disabilities. Learning Disabilities Quarterly, 28, 249-260.

National Office for School Counselor Advocacy. (2011). 2011 National survey of school counselors: Counseling at a crossroads. Retrieved from http://media.collegeboard.com/digitalServices/pdf/nosca/11b_4230_NarReport_BOOKL ET_WEB_111104.pdf

Newell, M., \& Kratochwill, T. R. (2007). The integration of response to intervention and critical race theory-disability studies: A robust approach to reducing racial discrimination in evaluation decisions. In S. R. Jimerson, M. K. Burns \& A. M. VanDerHeyden (Eds.), Handbook of response to intervention: The science and practice of assessment and intervention. New York: Springer. doi: 10.1007/978-0-387-49053-3_5 
Ockerman, M.S., Mason, E.C. M., Novakovic, A. (2012). The ABCs of TSC: How one counselor education department transformed its school counseling program. Journal for Counseling in Illinois. 1(3), 21-30.

Ockerman, M. S., Mason, E. C. M., \& Hollenbeck, A. F. (2012). Integrating RTI with school counseling programs: Being a proactive professional school counselor. Journal of School Counseling, 10(15).

O' Connor, E. P., \& Freeman, E. W. (2012). District level considerations in supporting and sustaining RTI implementation. Psychology in the Schools, 49(3), 297-310. doi: 10.1002/pits.21598

Patrikakou, E.N. (2004). Adolescence: Are parents relevant to students' high school achievement and post-secondary attainment? Invited manuscript at The Harvard Family Research Project. Family Involvement Network of Educators: Research Digests. Retrieved from: http://gseweb.harvard.edu/hfrp/projects/fine/resources/digest/adolescence.html

Patrikakou, E. N. (2008). The power of parent involvement: Evidence, ideas, and tools for student success. Lincoln, IL: The Center on Innovation and Improvement.

Patrikakou, E.N., Weissberg, R. P., Redding, S., \& Walberg, H. J. (Eds.) (2005), School-family partnerships: Fostering children's school success. New York, NY: Teachers College Press.

Pena, D. C. (2000). Parent involvement: Influencing factors and implications. The Journal of Educational Research, 94, 42-54. 
Penlington, C., Kington, A. \& Day, C. (2008). Leadership in improving schools: A qualitative perspective. School Leadership \& Management: Formerly School Organisation, 28(1), 65-82. doi: http://dx.doi.org/10.1080/13632430701800086

Perusse, R. \& Goodnough, G.E. (2001). A comparison of existing school counselor program content with the education trust initiatives. Counselor Education and Supervision, 41, 100-110. Retrieved from http://aca.metapress.com/openurl.asp?genre=article\&eissn=1556$\underline{6978 \& \text { volume }=41 \& \text { issue }=2 \& \text { spage }=100}$

Reschly, A.L. (2008). Schools, families and response to intervention. The RTI Action Network, National Center on Learning Disabilities. Retrieved from http://www.rtinetwork.org/essential/family/schools-familes-and-rti

Ryan, T. , Kaffenberger C.J, \& Carroll, A.G. (2011). Response to intervention: An opportunity for school counselor leadership. Professional School Counseling, 14(3), 211-221.

Sears, S. J. (1999). Transforming school counseling: Making a difference for students. NASSP Bulletin, 83, 47-53. Retrieved from http://bul.sagepub.com/

Smith, G., Kinard, L. \& Lozo, D. (2008). The integration of the Georgia student achievement pyramid of interventions with comprehensive school counseling: A framework that supports all students. Presentation for The Cobb County School District, Marietta, GA.

Sullivan, A. L. \& Long, L. (2010). Examining the changing landscape of school psychology practice: A survey of school-based practitioners' training and involvement in RTI. Psychology in the Schools, 47, 1059-1079. doi: 10.1002/pits.20524 
Sullivan, A. Long, L \& Kucera, M. (2011). A survey of school psychologists' preparation, participation, and perceptions related to positive behavior interventions and supports. Psychology in the Schools 48(10), 971-985.

US Department of Education, Office of Special Education and Rehabilitation Services (2011).

"A Response to Intervention (RTI) process cannot be used to delay-deny an evaluation for eligibility under the Individuals with Disabilities Education Act (IDEA).” Retrieved from http://www.wrightslaw.com/info/rti.osep.memo.0111.pdf.

Webb, L., Brigman, G. \& Campbell, C. (2005). Linking school counselors and student success: A replication of the student success skills approach targeting the academic social competence of students. Professional School Counseling, 8(5), 407-413.

Zambrano, E., Castro-Villarreal, F, Sullivan, J (2012). School counselors and school psychologists: Partners in collaboration for student success within RTI. Journal of School Counseling, 10(24).

Zirkel, P. (2012). The legal dimension of RTI: Part II - State laws and guidelines. RTI Action Network. Retrieved from http://rtinetwork.org/learn/ld/the-legal-dimension-of-rti-part-iistate-laws-and-guidelines.

Zirkel, P. A. (2011). State laws and guidelines for RTI: Additional implementation features. Retrieved from_http://www.nasponline.org/publications/cq/39/7/professional-practicestate-laws.aspx.

Zirkel, P. A., \& Thomas, L. B. (2010). State laws for RTI: An updated snapshot. Teaching Exceptional Children, 42(3), 56-63. 